\title{
Development of the Social-Media-based Blended Learning Course to Enhance Student Learning: A Case Study on a Social Science Course
}

\author{
Patchara Vanichvasin ${ }^{1}$ \\ ${ }^{1}$ Faculty of Education, Kasetsart University, Thailand \\ Correspondence: Patchara Vanichvasin. E-mail: feduprv@ku.ac.th
}

Received: June 11, 2018

Accepted: August 8, $2018 \quad$ Online Published: August 31, 2018

doi:10.5539/ass.v14n9p58

URL: https://doi.org/10.5539/ass.v14n9p58

\begin{abstract}
The purposes of this research were: 1) to develop a social-media-based blended learning course 2) to study the overall effectiveness of the developed learning course and 3) to examine student learning toward the developed learning course. Purposive sampling was used to select a research sample of 16 students who were enrolled in the selected social science course under the Business and Computer Education Program at Kasetsart University. Data analysis was presented using the mean, standard deviation, t-test and content analysis. The findings indicated that the developed social-media-based blended learning course consisted of five key elements, namely, live events, online content, collaboration, assessments and reference material. It was verified by experts as being of very high quality in its content, learning and application. The overall effectiveness covered flexibility, interaction, learning process, learning climate and engagement. The effectiveness had an overall mean at a high level $(\bar{x}=4.40, S D=0.42)$. The results from open ended questions revealed that students considered that the developed course was an effective learning tool because it was interesting, easy to understand and convenient to study anytime and anywhere. In addition, they thought that blending a course with the most-used technology supported their learning as it helped them review content knowledge, promoted discussion in-class and online and developed good academic skills in terms of being responsible for their own learning and exchanging of ideas. However, some students with time constraints and busy schedules suggested a reduction in online learning activities. As a result, most students liked the developed social-media-based blended learning course used in their learning process while the results of student learning showed that there was significant improvement after using the developed blended learning course. The difference proved that its use contributed to student learning. It can be concluded that a well-blended learning course that is implemented with the fundamentals, key elements and key factors influencing blended learning can be integrated with widely and extensively used technology as part of the teaching and learning process to positively improve student learning.
\end{abstract}

Keywords: social-media-based blended learning, student learning, social science course

\section{Introduction}

Conventional methods of teaching are no longer suitable for providing better-quality education to students pursuing higher learning; thus, universities are integrating different technologies in their mission to make teaching more innovative (DeNeui \& Dodge, 2006; Orhan, 2008). As a result, teaching in the 21st century involves the use of many technologies as a part of education to help students achieve learning outcomes and leverage their learning (Saxena, 2013) because technology is best viewed as a robust set of instructional tools that help accomplish the objectives of the teaching-learning process (Lever-Duffy \& McDonald, 2008). It not only makes the instruction more meaningful, but also helps students to learn what they are interested in faster and from a wider perspective (Havenstein, 2008).

The blended learning approach is considered as one of the technology-based methods that can be used due to an increasing awareness that it can significantly enhance the learning experience (Garrison \& Vaughan, 2008), suits the learning styles preferences of 21 st century learners (Wichadee, 2018), encourages interactivity and active participation among learners (Higgins \& Gomez, 2014), enriches students' learning (Pedro, 2005) and promotes high student satisfaction (Albrecht, 2006). The use of blended learning clearly relates to changes in higher education from tutor-centered approaches to a focus on learners (Higgins \& Gomez, 2014) via a combination of face-to-face and online delivery methods, with the aim of each complementing the other (Poon, 2013). Higher education turns to blended learning and this is recognized as one of the greatest trends in education today 
(Drossos et al., 2006). Yen and Lee (2011) also assert that blended learning, thoughtfully combining the best elements of online and face-to-face education, is likely to emerge as the predominant teaching model of the future because in blended learning environments, the learning process is accessible, inclusive and interactive (Bryson, 2003). It can be seen that blended learning is transforming learning and teaching in higher education (Higgins \& Gomez, 2014), offering the opportunity to overcome some of the shortfalls in traditional teaching methods (Hitch et al., 2013) and benefiting the educational process (Bourne and Seaman, 2005). Many research studies have demonstrated that courses using blending learning as a delivery method contribute to improved learning outcomes for students (Dwaik, Jweiless \& Shrouf, 2016; Poon, 2013; Francis \& Shannon, 2013; Lim \& Morris, 2009; Yates et al., 2009; Rossiou \& Sifaleras, 2007; O'Toole \& Absalom, 2003; Boyle et al., 2003).

Carman (2005) identified five key ingredients emerging as important elements of a blended learning process, namely, live events, online content, collaboration, assessment and reference material. Classroom learning must be active to make live events. Regarding online content, there are many online platforms to choose from in order to create a blended learning course. The online content knowledge in digital form is then developed. Learning activities are also created. Students are encouraged to study the content knowledge, participate in learning activities and be assessed based on those learning activities. When the key elements are fulfilled to give students a more rapid and wider perspective of the course content through two modes of learning, effectiveness is expected in terms of its flexibility, interaction, learning process, learning climate and engagement, which are considered as key benefits and challenges in implementing a blended learning course (Chen et al., 2014; Owston et al., 2013; McDonald, 2012; Ozkan \& Koseler, 2009; Ruiz et al., 2006; Manwaring et al., 2017; Holley \& Dobson, 2008).

In the Thai educational context, technology has played an important role in education (Deerajiviset, 2014) and there is increasing use of different technologies in higher education not only because educators recognize the impact of technology that can improve learning outcomes and increase learner engagement (Stein \& Graham, 2014) but also because the integration of technologies for education in the form of research and development was also promoted by the National Education Act B.E. 2542 (Ministry of Education, 1999). Furthermore, blended learning helps reach the goal of student-centered education in Thailand, which emphasizes student-centered education as blended learning being a fundamental redesign of the instructional model with a shift from lecture-centered to student-centered instruction where students become active and interactive learners (Poon, 2013). In Thailand, technology has become the key issue and has a significant influence on current education. Thailand has placed the issue of technology in education as its primary concern and this has been implemented throughout all levels of education for a variety of objectives (Ministry of ICT, 2009). Moreover, university students also expect flexible, innovative and engaging learning experiences with the different technologies that they commonly use or will be expected to use in today's professional, academic and social environments (Spiliotopoulos, 2011).

Although there are many online learning platforms that can produce blended learning with the use of technology, the most commonly used technology is expected to enrich student learning better than the least used one. In Thailand, social media is intensively, extensively and broadly used by students in their personal lives due to its ease of use, popularity, no requirements for advanced technical skills and the convenience of learning anywhere and anytime. Not only in Thailand is the social media platform considered as one of the most visited and used applications over the Internet (Bi, Qin \& Huang, 2014). Facebook is the most popular form of social media as it provides a platform for social networking, facilitating asynchronous and synchronous communication in an informal way. Such informality encourages more interaction among students and teachers. It also enables students to express their ideas in and after class and helps students to formulate their thoughts with the support of multimedia contents such as pictures, videos and hyperlinks to other URLs (Dyson et al., 2015). It is the platform most commonly and widely used by university students; a study of 3,000 university students found that 90\% used Facebook (Dahlstrom, Grunwald, de Boor, \& Vockley, 2011).

Many studies have investigated the use of blended learning in English language courses (Lim, 2015; Wichadee, 2018; Promsurin \& Vitayapirak, 2015; Chansamrong, Tubsree, \& Kiratibodee, 2014; Suwannasom \& Catane, 2016; Tananuraksakul, 2016; Rattanasak, 2017; Banditvilai, 2016; Sucaromana, 2013) but only a few have explored blended learning in social science courses. In particular, there has been no relevant research on a blended course in human resource management. Using a blended learning course in human resource management may be of great benefit to students to revise, reinforce and expand their learning from the classroom to online sessions with social media support, as it is believed that social media can help enrich education by providing blended learning experiences (Jones et al., 2010). Therefore, this study chose to conduct a case study using a social science course (human resource management), with integration of the most used 
forms of social media technology such as Facebook because several previous studies have adopted Facebook to set a blended learning setting in the Thai educational context (Tananuraksakul, 2014; Rattanasak, 2017; Pimoubol \& Sriwattanarothai, 2016) and succeeded in achieving the established learning outcomes through social media support.

Based on the findings of numerous researchers investigating the results of blending a course with extensively used technology in English language courses, the researcher was interested in developing a social-media-based blended learning course in a social science course (human resource management), studying its effectiveness, and examining student learning with the expectation that blending a course with the most-used technology would provide the same positive results and lead to successful learning

\section{Research Objectives}

2.1 To develop a social-media-based blended learning course.

2.2 To study the overall effectiveness of the developed learning course.

2.3 To examine student learning towards the developed learning course

\section{Method}

The research design used both qualitative and quantitative approaches which were applied to the human resource management course at Kasetsart University as a case study. The research objective details were as follows.

\subsection{Subjects}

The subjects were 16 students who enrolled in a human resource management course in the first semester of 2017. They were majoring in the fields of Business and Computer Education at Kasetsart University in Thailand. The sample size was small as it was mandatory the batch of third year students to register in this course. They were selected using purposive sampling to participate in this study. However, the researcher was aware that the research findings were specific to this study and may not be referred to other groups and subjects due to the limitation of the purposive sampling applied.

\subsection{Instruments}

The following research instruments were used to develop the social-media-based blended learning course, study the overall effectiveness and examine student learning.

\subsubsection{The Developed Social-Media-Based Blended Learning Videos}

Nine video clips were developed by the researcher to be used in the social media program in blended learning by students studying in the human resource management course. The clips were revised, reinforced and expanded from a classroom session including online learning activities related to the content of each video clip. Students were further challenged by online learning activities because all activities were not identical to classroom learning but rather were parallel and supplementary. Before use, the clips were reviewed by three experts in the field of technology and technology-based education using an appropriateness questionnaire to confirm that the content was similar to that in the in-class course and that the clips were appropriate for use in blended learning with targeted subjects.

\subsubsection{Appropriateness Questionnaire}

The appropriateness questionnaire was developed to obtain experts' opinions about the developed social-media-based blended learning course. The researcher developed it based on the design of the blended learning course in three dimensions, that is, content, learning, and application using a Likert scale with 5 levels on the appropriateness for use and one open-ended question for further recommendations. The questionnaire consisted of two parts. Part 1 contained 10 items in three dimensions with statements 1-3 aiming at information on its content and statements 4-6 aiming at information on its learning, while statements 7-10 aimed at information on its application. Part 2 was one open-ended question for further recommendations so that a more descriptive response to the overall appropriateness could be added. The responses from the rating scale were ranked as 1 very low, 2 low, 3 average, 4 high and 5 very high on appropriateness for use, while the responses from the one open-ended question were considered regarding further recommendations. All results and comments for improvement were considered.

\subsubsection{Effectiveness Questionnaire}

The effectiveness questionnaire was developed to study the overall effectiveness of using the developed social-media-based blended learning course to supplement an in-class course and to enhance learning from student's opinions. The researcher developed it based on a literature review of the effectiveness of blended 
learning. The questionnaire consisted of two parts. Part 1 contained 15 items in five dimensions with statements 1-3 aiming at information on flexibility, statements 4-6 aiming at information on interaction, statements 7-9 aiming at information on learning process, statements 10-12 aiming at information on learning climate and statements 13-15 aiming at information on engagement. Part 2 was one open-ended question for further recommendations so that a more descriptive response to the overall effectiveness could be added. The items were measured using a 5-point Likert scale ranging from 1 (very low) to 5 (very high) and on further recommendations. For validity, the questionnaire was reviewed by three experts to determine whether the instrument covered the effectiveness of blended learning that was the targeted requirement for evaluation. All items were calculated using the index of congruence (IOC) with values between 0.67 and 1.00. Reliability was pilot tested using 20 students to ensure that the language used was understood by students and the questions elicited the required information. All items were calculated using the coefficient alpha technique with reliability values of 0.868 . Therefore, the questionnaire could be used to evaluate the overall effectiveness of the developed social-media-based blended learning course from targeted subjects.

\subsubsection{Reflective Journal}

The reflective journal was developed to elicit the views of students on their likes and dislikes after using the developed social-media-based blended learning course. It was approved by experts on its appropriateness for reflecting on likes and dislikes of the use of the social-media-based blended learning course.

\subsubsection{Achievement Tests}

There were two achievements tests with total scores of 100 to measure student learning at the end of the research study. The pre-test and post-test related to the content knowledge of human resource management and were used as the first achievement test. It contained 10 multiple choice items with four types of choices. A score of 1 was given when students gave the correct answer, with a score of 0 if they did not. The maximum total score was 10 . The three experts considered that the test was appropriate to be used with index of congruence (IOC) values between 0.67 and 1.00. The researcher tried out the test with a non-targeted sample of 20 students before using with the targeted sample of 16 students. The test was calculated using the coefficient alpha technique with average reliability values of 0.748 . The value of each item was assessed by the difficulty and discrimination indices. The range for the difficulty index was between 0.60 and 0.70 , for which the preferred range was between 0.20 and 0.80 and the range for discrimination index was between 0.40 and 0.70 , for which the preferred range was between 0.20 and 1.00. The writing tests to demonstrate effective human resource management were used as the second achievement test. There were nine writing tests each worth a maximum score of 10 (total maximum score were 90). The three experts considered that the tests were appropriate to be used with IOC values between 0.67 and 1.00. The researcher tested the writing tests with a non-targeted sample of 20 students before using with the targeted sample of 16 students. The value of each item was assessed using the difficulty and discrimination indices. The range for the difficulty index was $0.79-0.80$, for which the preferred range was $0.20-0.80$ and the range for the discrimination index was $0.32-0.43$, for which the preferred range was $0.20-1.00$. The writing test scores were calculated using the coefficient alpha technique with reliability values of 0.951 .

\subsection{Procedures}

This study used a case study to investigate the developed social-media-based blended learning course as follows.

Stage 1: Design the case study

In this stage, the researcher analyzed and synthesized the fundamentals, key elements, related research concerning blended learning, its effectiveness and student learning from the literature review. The researcher used information obtained as the conceptual framework to develop the social-media-based blended learning course. Related research was used to help build a proper developmental framework for use. Next, the human resource management course, one of the available social science courses, was selected based on its importance in laying the foundation for the workplace environment when students entered their practicum and started working in organizations in the future. This course was also a required core course for students in the Business and Computer Education Program. For a suitable blended learning setting, this course was adjusted to incorporate social media platforms like Facebook and included both live events and online content. It was a three-unit course, which was taken by third year undergraduate students as a mandatory course. The researcher designed a 15 -week course plan as the case study. The social-media-based blended learning course was developed with fundamentals and key elements according to the established conceptual framework.

Stage 2: Conduct the case study

This study was conducted as part of a real educational offering. This class was small in size as it was reserved for 
only the same batch of third year students in the Business and Computer Education Program. All students were registered for this mandatory course and participated in this study over one teaching semester. In this stage, the researcher, as a teacher, delivered the developed social-media-based blended learning course with a combination of classroom and online learning to the 16 students who were selected as the case study for 3 hours each week during the 15-week period in the first semester of the 2017 academic year. The classroom sessions were initiated for 10 weeks followed by the blended learning approach for 5 weeks. All students were introduced to the concept of blended learning and did a pre-test prior to studying. The teacher presented content to students in classroom sessions and proceeded with the digital content in online sessions using a social media program to enable students to review, reflect on and discuss the digital content given.

Classroom sessions involved lectures, active learning activities and class discussion. Students had to study in class for 10 weeks. The teacher met with students face-to-face for the regular scheduled classes. For online learning, Facebook was selected as the social media technology to support blended learning due to its ease of access, popularity, convenience for learning anywhere and anytime and it required no advanced technical skills. A Facebook group using some features of writing posts, adding videos and asking questions was established specifically for the purpose of the study as a closed group to set up the online learning part, which was one of key elements of the blended learning process. Online sessions included nine video clips posted on the Facebook group every 3-4 days during the 5 weeks for review, reflection and discussion whenever and wherever students preferred. Students were encouraged to discuss and express their points of views on each video clip posted on the Facebook group. Learning in classroom and through online learning was connected to provide an integrated blended learning experience.

After week 10, the researcher, as the teacher, finished the classroom learning and started the online learning via the Facebook social media program to involve students in communication and collaboration with peers and the teacher in the learning activities on the social media platform. The researcher used nine writing tests with a possible maximum total score of 90 to discuss and assess students and to present essential learning material regarding the online learning activities posted on Facebook, which was extensively used by students. Students were encouraged to participate and interact with peers and the teacher in the learning process through the Facebook group.

\subsection{Data Collection and Analysis}

Stage 3: Analyze the case study

In this stage, the developed social- media-based blended learning course was reviewed by experts with the use of the appropriateness questionnaire to determine its appropriateness for use. The mean, standard deviation and content analysis were used to analyze the quantitative and qualitative data for interpretation based on the scores and further recommendations. The mean and standard deviation were used to analyze the quantitative data and to identify levels of appropriateness, while content analysis was used to analyze the qualitative data and to identify further recommendations based on the expert's comments. The scales used in the data interpretation were:

\section{Likert scale range Meaning}

4.51 to $5.00 \quad$ Very high

3.51 to $4.50 \quad$ High

2.51 to $3.50 \quad$ Average

1.51 to $2.50 \quad$ Low

1.00 to $1.50 \quad$ Very low

Next, the developed social-media-based blended learning course was pilot tested using non-targeted subjects based on the effectiveness questionnaire and reflective journal. Necessary changes were made to improve the course according to the experts' scores, recommendations and suggestions from non-targeted subjects.

Targeted subjects used the developed social-media-based blended learning course. The effectiveness questionnaire and reflective journal were then administered to the 16 students who had enrolled in the selected course. Subjects responded to the statements using the five-point scales and commented on the open-ended questions regarding the overall effectiveness of the course. The subjects' responses were analyzed using mean scores and their standard deviations based on the five-point Likert scale using the same interpretation mentioned above and also using the responses to the open-ended questions. The results and comments of the targeted subjects were analyzed using the mean, standard deviation and content analysis.

Students were also given two achievement tests used as a pre-test and post-test to examine their learning. To 
compare pre-test and post-test scores, a Dependent Sample T-test was used with a significance level of 0.05 to find the value of mean and standard deviation, and to compare the differences in the scores of the two tests before and after using the developed social-media-based blended learning course.

After analyzing the case study, the conclusions, recommendations and implications were reported to indicate the impact gained from this study.

\section{Results}

\subsection{Developed Social-Media-Based Blended Learning Course}

The fundamentals of blended learning were an integration of face-to-face instruction or classroom-based instruction with online instruction or technology-based instruction. Therefore, the developed social-media-based blended learning course consisted of five important elements as below:

1. Live events. These were led by the researcher as the teacher of the human resource management course for a period of 10 weeks and all students participated in live events at the same time in the classroom. Examples of live events were lectures related to human resource management, active learning activities and class discussion.

2. Online contents. These were learning experiences that all students completed at their own speed regardless of time and location for a period of 5 weeks through most used social media technology (Facebook). Examples of the online content used were the nine video clips related to human resource management, online learning activities and discussion of each video clip.

3. Collaboration. The learning environment was established using Facebook to enable students to communicate and collaborate with peers and the researcher as the teacher in the blended learning course.

4. Assessment. There were two achievement tests to measure students' knowledge. Pre-assessment was done before conducting live events and post-assessment was done after completing the online learning to measure student learning.

5. Reference material. Students were given handouts in class and digital content was posted in the form of video clips via Facebook as reference material.

As a result, the developed social-media-based blended learning course consisted of nine video clips that revised, reinforced and expanded classroom learning including learning activities related to the content of each video. Students were further challenged by online learning activities because all activities were not identical to the classroom learning but rather parallel and supplementary. The nine video clips were developed by the researcher specifically for the students studying in the selected human resource management course. The developed blended learning course was reviewed by three experts in the field of technology and technology-based education using an appropriateness questionnaire to confirm that the course covered similar content to the in-class course and was appropriate for use with the targeted subjects. Table 1 illustrates the appropriateness of the developed social-media-based blended learning course according to the experts' opinions.

Table 1. Mean and standard deviation of the developed social-media-based blended learning course's appropriateness based on the experts' opinions statement

X $\quad$ Standard deviation $\quad$ Appropriateness level

\section{Content}

1.The content is suitable for students

5.00

2.The content is clear and easy to understand

3.The online content is in accordance with in-class content

\section{Learning}

4. Social media helps stimulate learning

5.Video clips help stimulate learning

6. Learning activities helps stimulate learning

\section{Application}

7. The blended learning course is convenient for use

8. The blended learning course is easy to understand

9. The blended learning course presents content knowledge in accordance with in-class content

Total
5.00

5.00

4.67

4.33

4.33

4.67

4.33

5.00

4.70
0.00

0.00

0.00

0.58

0.58

0.58

0.58

0.58

0.00

0.06
Very high

Very high

Very high

Very high

High

High

Very high

High

Very high

Very high 
Table 1 shows that the overall mean score of appropriateness was at a very high level $(\overline{\mathrm{x}}=4.70, \mathrm{SD}=0.06)$. When looking at details, the mean scores were at very high levels for nearly all items. Only three items out of 10 were at high levels. In particular, the mean score of content was at a very high level $(\overline{\mathrm{X}}=5.00, \mathrm{~S} . \mathrm{D} .=0.00)$. The mean score of learning was at a high level $(\overline{\mathrm{x}}=4.44, \mathrm{SD}=0.51)$ and the mean score of its application was at a very high level $(\overline{\mathrm{x}}=4.67, \mathrm{SD}=0.33)$. The results from open-ended questions revealed that some experts suggested that the video clips should be made more interesting with the addition of graphics and animation.

The developed social-media-based blended learning course was then pilot tested with non-targeted subjects to ensure that language and learning activities were understood. Most of these subjects liked it while some of them agreed that a blended learning course supported student learning because they could learn anytime but a teacher must be well-prepared in blending technology in the course with a good design to enhance student learning.

\subsection{Overall Effectiveness of the Developed Social-Media-Based Blended Learning Course}

The overall effectiveness of the developed social-media-based blended learning consisted of five factors influencing the effectiveness according to the literature review, namely, flexibility, interaction, learning process, learning climate and engagement, which were used as indicators to identify whether or not the blended learning course was effective. Table 2 illustrates the overall effectiveness from implementing the developed social-media-based blended learning course.

Table 2. Mean and standard deviation of the overall effectiveness of the developed social-media-based blended learning course from students' opinions

\begin{tabular}{|c|c|c|c|}
\hline Statement & $X$ & $\begin{array}{l}\text { Standard } \\
\text { deviation }\end{array}$ & $\begin{array}{c}\text { Effectiveness } \\
\text { level }\end{array}$ \\
\hline \multicolumn{4}{|l|}{ Flexibility } \\
\hline 1. Access content easily and conveniently & 4.50 & 0.52 & High \\
\hline 2. Ability to control own learning & 4.44 & 0.63 & High \\
\hline 3. Flexible in selecting learning according to needs & 4.63 & 0.50 & Very High \\
\hline \multicolumn{4}{|l|}{ Interaction } \\
\hline 4. Stimulate interaction with course content & 4.00 & 0.63 & High \\
\hline 5.Opportunities to interact with teachers and peers & 4.19 & 0.54 & High \\
\hline 6. Interact through different channels & 4.31 & 0.60 & High \\
\hline \multicolumn{4}{|l|}{ Learning process } \\
\hline 7. Manage learning time suitably & 4.38 & 0.96 & High \\
\hline 8. Promote learning in class and online & 4.19 & 0.54 & High \\
\hline 9. Expand learning to the maximum & 4.38 & 0.89 & High \\
\hline \multicolumn{4}{|l|}{ Learning climate } \\
\hline 10. Learning suits to individual needs & 4.44 & 0.73 & High \\
\hline 11. Learn easily and conveniently & 4.75 & 0.45 & Very high \\
\hline 12. Integrate technology to support and promote learning & 4.81 & 0.40 & Very high \\
\hline \multicolumn{4}{|l|}{ Engagement } \\
\hline 13. Stimulate engagement & 4.44 & 0.63 & High \\
\hline 14. Create environment suitable for learning and participation in learning & 4.31 & 0.70 & High \\
\hline 15. Achieve expected learning outcomes & 4.25 & 0.77 & High \\
\hline Total & 4.40 & 0.42 & High \\
\hline
\end{tabular}

Table 2 shows that the overall mean score of the effectiveness of the developed social-media-based blended course was at a high level $(\overline{\mathrm{x}}=4.40, \mathrm{SD}=0.42)$. In particular, the means scores of flexibility and learning climate were at very high levels $(\overline{\mathrm{x}}=4.52, \mathrm{SD}=0.40, \overline{\mathrm{x}}=4.67, \mathrm{SD}=0.38$, respectively). The mean scores of interaction, learning process, and engagement were at high levels $(\overline{\mathrm{x}}=4.17, \mathrm{SD}=0.47, \overline{\mathrm{x}}=4.31$, S.D. $=0.58, \overline{\mathrm{x}}$ $=4.33$, S.D. $=0.57$, respectively). When considering all factors influencing the effectiveness, the mean score of 
learning climate was the highest while the mean score of interaction was the lowest.

Almost all students expressed their comments and suggestions on the developed social-media-based blended learning course. Results from open-ended questions revealed that students considered that the developed social-media-based blended learning course was an effective learning tool because it was interesting, easy to understand and convenient to study anytime they wanted. In addition, they thought that blending a course with technology supported their learning as it helped them review the content knowledge, promoted discussion both for in-class and online sessions and developed good academic skills such as being responsible for their own learning and exchanging ideas. However, some students suggested that a reduction of learning activities due to student time constraints and busy schedules would be good. Table 3 displays student views reflecting from using the developed social-media-based blended learning course.

Table 3. Students' views on the developed social-media-based blended learning course

\begin{tabular}{|c|c|c|c|}
\hline Comments & Category & Detail & $\begin{array}{c}\text { Number of } \\
\text { students }\end{array}$ \\
\hline \multirow{6}{*}{ Like } & \multirow{2}{*}{ Skills building } & - $\quad$ Express and share views academically & 3 \\
\hline & & - Practice thinking for answers & 2 \\
\hline & \multirow{3}{*}{$\begin{array}{c}\text { Learning } \\
\text { management }\end{array}$} & - Good, fun, interesting and innovative way of learning & 4 \\
\hline & & - $\quad$ Learn anytime anywhere from various devices & 5 \\
\hline & & - Learning activities in accordance with content knowledge & 1 \\
\hline & $\begin{array}{l}\text { Time } \\
\text { management }\end{array}$ & $\begin{array}{l}\text { - Support learning due to time constraints because there were } \\
\text { university and public holidays affecting their schedule }\end{array}$ & 1 \\
\hline \multirow{4}{*}{ Dislike } & \multirow{3}{*}{$\begin{array}{c}\text { Learning } \\
\text { arrangement }\end{array}$} & - $\quad$ Miss Facebook, miss activities & 1 \\
\hline & & - Unorganized and scattered activities on Facebook & 1 \\
\hline & & - $\quad$ Required subtitles on video clips & 1 \\
\hline & $\begin{array}{c}\text { Time } \\
\text { management }\end{array}$ & $\begin{array}{ll} & \text { Set exact deadlines for online learning activities }\end{array}$ & 1 \\
\hline
\end{tabular}

Table 3 shows that most of students liked the developed social-media-based blended learning course because they could use it anytime and anywhere from various devices. In addition, they liked it because it was a good, fun, interesting and an innovative way of learning outside classroom. Some of them liked the fact that they could express and share their opinions academically in learning activities, which activated them to find answers and exchange their answers with peers and the teacher.

\subsection{Student Learning}

Dependent Sample T-test was used to compare the means between the two related groups on two occasions for the same continuous dependent variable (student learning) and to examine whether there was a statistical difference between the means of student learning before and after using the developed social-media-based blended learning course. Assumption checking was carried out prior to statistical procedures. No missing data or significant outliers in the differences between the two related groups were found. The distribution of the differences in the dependent variable was normally distributed. Assumptions were met for both the pre-and post-test scores of the two related groups and their testing indicated no violation of assumptions. Therefore, the scores from 0 to 100 obtained from the two achievement tests were analyzed using the Dependent Sample T-test. Table 4 illustrates student learning in the pre-tests and post-tests of targeted subjects.

Table 4. Student learning from scores of pre-tests and post-tests

\begin{tabular}{ccccccc}
\hline Targeted Subject & $\mathrm{N}$ & Mean & Standard deviation & $\mathrm{t}$ & $\mathrm{df}$ & Sig. (2-tailed) \\
\hline Pre test & 16 & 79.50 & 6.72 & -12.79 & 15 & 0.000 \\
Post test & 16 & 97.12 & 2.36 & & & \\
\hline
\end{tabular}

Table 4 shows the results of the pre-test and post-test for the targeted subjects. The mean scores for the pre-test and post-test were 79.50 and 97.12 , respectively. The mean score of the post-test was much higher than the mean 
score of the pre-test and the paired t-test results were significant (less than the alpha value (0.05) with $\mathrm{t}=-12.79$, $\mathrm{df}=15$ ). These results indicated that there were significant differences between the pre-and post-test performance of the targeted subjects after using the developed social-media-based blended learning course.

\section{Conclusion and Discussion}

The main findings indicated that students perceived the overall effectiveness of the developed social-media-based blended learning course at a high level because it could significantly increase their learning as the research results demonstrated that the post-test scores were higher than the pre-test scores. As a result, students learnt better from a blended learning course that was well designed and implemented with fundamentals, key elements and key factors influencing the effectiveness of a blended learning course, namely, flexibility, interaction, learning process, learning climate and engagement. This was in accordance with Kiviniemi (2014) who reported that it was important to examine how students experience the blended learning course and their feedback on its effectiveness to make sure that a blended learning course gave positive results in reaching the expected learning outcomes, and Dziuban et al. (2004) who studied the effectiveness of blended learning in a group of university students and found that blended learning led to students' higher grades.

In addition, students perceived a blended learning course with the most commonly used technology as an effective learning tool that could enrich their learning. This was in accordance with Dzuiban, Hartman, \& Moskal (2004) who reported that blended learning is an essential learning process to enhance the efficiency and quality of learning because it combines the effectiveness of the online environment and the socialization opportunities of the classroom with technology-based learning. Furthermore, Banyen et al. (2016) found that Thai tertiary-level students were satisfied with blended learning when doing their computer-based assignment outside of the classroom.

It is also interesting to see that the use of social media enabled communication and collaboration resulting in student interaction and engagement in all learning activities, which was in accordance with Grosch et al. (2014) who stated that learning in the context of social media has become an integral part of the academic experience. This result was also supported by Hazari et al, (2009) who stated that educational institutions are progressively implementing social media to support learning and teaching activities, and Chan \& Leung (2016) who reported that social media provide innovative ways for enhancing communication and collaboration in the educational context, thus raising the learning and teaching practices onto a new level. Learning outside the classroom through social media made communication and collaboration possible as the social media was considered as a powerful learning platform (especially Facebook), which could support learning anywhere and anytime, providing students have an online platform and internet connection. Moreover, Irwin et al. (2012) studied four university courses using Facebook and reported that $78 \%$ of the students thought Facebook was an effective learning tool that enhanced discussion, interaction and provided access to posted assessments and lecture notes, McCarthy (2010) found that $95 \%$ of students in a survey agreed that Facebook assisted them in the development of peer relationships and appreciated the collaborative discussion in the online environment.

In conclusion, the research findings showed that a well designed and implemented blended learning course with fundamentals, key elements and key factors influencing blended learning was useful and effective when the course was integrated with extensively used technology, especially social media. However, there were some limitations in this study. The sample size was relatively small because the selected course was reserved for the same batch of third year students only; thus, their results may not be relevant to other groups of students. Furthermore, using a control and experimental group of samples may give a clearer result regarding using blended learning instead of using just one group which precluded division into two cohorts. These limitations must be considered before future courses are implemented so that blended learning can be integrated in other courses as an effective teaching and learning tool for maximum success in student learning.

\section{References}

Albrecht, B. (2006) Enriching student experience through blended learning. Retrieved from http://www.educause.edu/ir/library/pdf/ecar_so/erb/ERB0612.pdf.

Banditvilai, C. (2016). Enhancing students' language skills through blended learning. The Electronic Journal of e-Learning, 14 (3), 220-229.

Banyen, W, Viriyavejakul, C., \& Ratanaolarn, T. (2016). A blended learning model for learning achievement enhancement of Thai undergraduate students. International Journal of Emerging Technologies in Learning, 11(4), 48-55. https://doi.org/10.3991/ijet.v11i04.5325

Bi, J., Qin, Z., \& Huang, J. (2014). Detecting community and topic co-evolution in social networks. 
TELKOMNIKA Indonesian Journal of Electrical Engineering, 12(5), 4063-4070.

Bourne, K., \& Seaman, J. (2005). Sloan-C special survey report: A look at blended learning. Needham, MA: The Sloan Consortium.

Boyle, T., Bradley, C., Chalk, P., Jones, R., \& Pickard, P. (2003). Using blended learning to improve student success rates in learning to program. Journal of Educational Media, 28(2-3), 165-178. https://doi.org/10.1080/1358165032000153160

Bryson, J. (2003). Universal instructional design in postsecondary settings: an implementation guide. Retrieved from http://www.mohawkcollege.ca/dept/stdev/Disability/UID-manual.pdf

Carman, J. M. (2005). Blended learning design: five key ingredients. Retrieved from https://www.it.iitb.ac.in/ s1000brains/rswork/dokuwiki/media/5_ingredientsofblended_learning_design.pdf

Chan, W.T.Y., \& Leung, C.H. (2016). The use of social media for blended learning in tertiary education. Universal Journal of Educational Research, 4(4), 771-778.

Chansamrong, A., Tubsree, C., \& Kiratibodee, P. (2014). Effectiveness of cooperative and blended learning to assist Thai ESL students in learning grammar. HRD Journal, 5(2), 105-115.

Chen, Y., Wang, Y., \& Chen, N.-S. (2014). Is FLIP enough? Or should we use the FLIPPED model instead? Computers \& Education, 79, 16-27. https://doi.org/10.1016/j.compedu.2014.07.004

Dahlstrom, E., Walker, J., \& Dziuban, C. (2013). ECAR study of undergraduate students and information technology: 2013. Retrieved from https://library.educause.edu/ /media/files/library/2014/10/ers1406.pdf

Deerajviset, P. (2014). Technology in EFL teaching and learning in Thailand: an overview of research and issues. Journal of Mekong Societies, 10(1), 71-112.

DeNeui, D., \& Dodge, T. (2006). Asynchronous learning networks and student outcomes: The utility of online learning components in hybrid courses. Journal of Instructional Psychology, 33(4), 256-259.

Drossos, L., Vassiliadis, B., Stefani, A., Xenos, M., Sakkopoulos, E. \& Tsakalidis, A. (2006) Introducing ICT in traditional higher education environment: Background, design and evaluation of a blended approach. International Journal of Information and Communication Technology Education, 2(1), 65-78.

Dziuban, C. D., Hartman, J. L., \& Moskal, P. D. (2004). Blended learning. EDUCAUSE Center for Applied Research Bulletin, 7, 1-12.

Dziuban, C. D., Hartman, J. L, Moskal, P. D., Sorg, S., \& Truman, B. (2004). Three ALN modalities: An Institutional perspective. In J. Bourne \& J.C. Moore (Eds.), Elements of quality online education: Into the Mainstream (pp. 127-148). Needham, MA: Sloan-C.

Dwaik, R., Jweiless, A., \& Shrouf, S. (2016). Using blended learning to enhance student learning in American Literature courses. TOJET: The Turkish Online Journal of Educational Technology, 15(2), 126-137.

Dyson, B., Vickers, K., Turtle, J., Cowan, S. \& Tassone, A. (2015). Evaluating the use of Facebook to increase student engagement and understanding in lecture-based classes. Higher Education, 69(2), 303-313.

Francis, R., \& Shannon, S. J. (2013). Engaging with blended learning to improve students' learning outcomes. $\begin{array}{llll}\text { European Journal of Engineering 389-369. } & \text { Education, }\end{array}$ https://.doi.org/10.1080/03043797.2013.766679

Garrison, D. R., \& Vaughan, N. D. (2008). Blended learning in higher education: Frameworks, principles and guidelines. San Francisco, CA: Jossey-Bass.

Grosch, M., Berger, R., Gidion, G. \& Romeo, M. (2014). Which media services do students use in fact? Results of an international empirical survey. Procedia - Social and Behavioral Sciences, 141, 795-806.

Havenstein, H. (2008). Companies are looking for new ways to measure Web 2.0. Computerworld, 42(45), 14-15.

Hazari, S., North, A., \& Moreland, D. (2009). Investigating pedagogical value of wiki technology. Journal ofInformation Systems Education, 20(2), 187-198.

Higgines, D., \& Gomez, A. (2014). Teaching English studies through blended learning. Retrieved from https://www.heacademy.ac.uk/system/files/resources/teaching_english_studies_through_blended_learning.p df.

Hitch, G., Williams, J., Haberland, A., Bowen, J., Jardine, S., Power, P., \& Venstone, G. (2013). The use of 
videos in blended learning to enhance students ${ }^{\text {ee }}$ learning in system-based patient assessment with development of associated clinical skills: an analysis. Pharmacy Education, 13(1), 157-161.

Holley, D., \& Dobson, C. (2008). Encouraging student engagement in a blended learning environment: The use of contemporary learning spaces. Learning, Media and Technology, 33(2), 139-150.

Mohd, I. H., Aluwi, A. H., Hussein, N., \& Omar, M. K. (2016). Enhancing Students Engagement through Blended Learning Satisfaction and Lecturer Support. In IEEE $8^{\text {th }}$ International Conference on EngineeringEducation, Kuala Lumpur, Malaysia, 2016.Irwin, C., Ball, L., Desbrow, B., \& Leveritt, M. (2012). Students' perceptions of using Facebook as an Interactive learning resource at university. Australasian Journal of Educational Technology, 28(7), 1221-1232.

Jones, N., Blackey, H., Fitzgibbon, K., \& Chew, E. (2010). Get out of MySpace! Computers \& Education, 54(3),776-782.

Kiviniemi, M. (2014). Effects of a blended learning approach on student outcomes in a graduate-level public health course. BMC Medical Education, 14(47), 1-7.

Lever-Duffy, J., \& McDonald, J. B. (2008). Teaching and learning with technology (3rd ed.). Boston, MA: Pearson Education Incorporated.

Lim, S. (2015). A blended learning case study: the application of station rotation model in ELT listening and speaking class at Phayao Pittayakhom School. Paper presented at the International Conference on Language, Literature, Culture and Education.

Lim, D. H., \& Morris, M. L. (2009). Learner and instructional factors influencing learning outcomes within a blended learning environment. Educational Technology \& Society, 12(4), 282-293. Retrieved from http://www.jstor.org/stable/jeductechsoci.12.4.282

Manwaring, K.C., Larsenb, R., Grahamb, C.R., Henrieb, C.R., \& Halversonb, L.R. (2017). Investigating student engagement in blended learning settings using experience sampling and structural equation modeling. The Internet and Higher Education, 35(2017), 21-33.

McCarthy, J. (2010). Blended learning environments: Using social networking sites to enhance the first year experience. Australasian Journal of Educational Technology, 26(6), 729-740. Retrieved from $\mathrm{http}: / /$ www.ascilite.org.au/ajet/ajet26/mccarthy.html

McDonald, P. L. (2012). Adult learners and blended Learning: A phenomenographic study of variation in adult learners' experiences of blended learning in higher education. The George Washington University.

Ministry of Education. (1999). National Education Act B.E 2542. Retrieved from http://web.krisdika.go.th/data/law/law2/\%a198/\%a198-20-9999-update.pdf

Ministry of ICT. (2009). ICT for Education Master Plan 2007-2011. Bangkok: Ministry of ICT.

Orhan, F. (2008). Redesigning a course for blended learning environment. Turkish Online Journal of Distance Education, 9(1), 54-66.

O'Toole, J. M., \& Absalom, D. J. (2003) The impact of blended learning on student outcomes: Is there room on the horse for two? Journal of Educational Media, 28(2-3), 179-190.

Owston, R., York, D., \& Murtha, S. (2013). Student perceptions and achievement in a university blended learning strategic initiative. The Internet and Higher Education, 18, 38-46. https://doi.org/10.1016/j.iheduc.2012.12.003

Ozkan, S., \& Koseler, R. (2009). Multi-dimensional students' evaluation of e-learning systems in the higher education context: An empirical investigation. Computers and Education, 53, 1285-1296. https://doi.org/10.1016/j.compedu.2009.06.011.

Pedro, F. (2005). Comparing traditional and ICT-enriched university teaching methods: evidence from two empirical studies. Higher Education in Europe, 30(3-4), 399-411. http://dx.doi.org/10.1080/03797720600625937.

Pimoubol, T., \& Sriwattanarothai, N. (2016). Blended learning unit: a case of using Facebook as a learning tool to teach gene expression in higher education. Teaching and Learning with Technology, 2016, 1-11. https://doi.org/10.1142/9789814733595_0001

Poon, J. (2013). Blended learning: An institutional approach for enhancing students' learning experiences. MERLOT Journal of Online Learning and Teaching, 9(2), 271-289. 
Promsurin, S., \& Vitayapirak, J. (2015). Comparison of e-Learning, blended and traditional English teaching methods: A case study of Ban Hong Community Education College. International Journal of Languages, Literature and Linguistics, 1(2), 80-86.

Rattanasak, S. (2017). Blended language learning: using Facebook as a pedagogical tool to enhance Thai EFL learners' reading comprehension through internet-based reading materials. Proceedings of the European Conference on Language Learning 2017, 87-98.

Rossiou, E., \& Sifaleras. (2007). A. Blended Methods to Enhance Learning: An Empirical Study of Factors Affecting Student Participation in the use of e-Tools to Complement F2F Teaching of Algorithms. Proceedings of the European Conference on e-Learning, Copenhagen, Denmark, 2007, 519-528.

Ruiz, J. G., Mintzer, M. J., \& Leipzig, R. M. (2006). The impact of E- learning in medical education. Academic Medicine, 81, 207-212.

Saxena, S (2013). How important is use of technology in education. Retrieved from http://www.edtechreview.in/news/681-technology-in-education.

Spiliotopoulos, V. (2011). Towards a technology-enhanced university education. In A. Kitchenham (Ed.), Blended learning across disciplines: Models for implementation (pp. 1-16). Prince George: University of Northern British Columbia.

Stein, J., \& Graham, C. R. (2014). Essentials for Blended Learning. New York, NY: Routledge.

Sucaromana, U. (2013). The effects of blended learning on the intrinsic motivation of Thai EFL students. English Language Teaching, 6(5), 141-147.

Suwannasom, T., \& Catane, N. G. (2016). Exploring university students' attitudes and strategies in a blended English language learning environment. KKU International Journal of Humanities and Social Sciences, 6(1), 10-31.

Tananuraksakul, N. (2014). Use of facebook group as blended learning and learning management system in writing. Teaching English with Technology, 14(3), 3-15.

Tananuraksakul, N. (2016). Blended e-learning as a requirement for teaching EFL in a Thai academic context. Teaching English with Technology, 16(4), 48-55.

Wichadee, S. (2018). Significant predictors for effectiveness of blended learning in a language course. Jaltcalljournal, 14(1), 25-42.

Yates, B. A., Bakia, M., Means, B., \& Jones, K. (2009). Evaluation of evidence-based practices in online learning: A meta-analysis and review of online learning studies. Retrieved from http://edicswebed.gov/edics_files_web/03898/Att_References and Glossary.doc.

Yen, J. C., \& Lee, C. Y. (2011). Exploring problem solving patterns and their impact on learning achievement in a blended learning environment. Computers \& Education, 56(1), 138-145. https://doi.org/10.1016/j.compedu.2010.08.012.

\section{Copyrights}

Copyright for this article is retained by the author(s), with first publication rights granted to the journal.

This is an open-access article distributed under the terms and conditions of the Creative Commons Attribution license (http://creativecommons.org/licenses/by/4.0/). 